\title{
Improving Checklists of Alien Plants with Digitised Herbarium Collections: The Example of D.R. Congo (Africa)
}

\section{Farzaneh Bordbar}

Universite Libre de Bruxelles

Pierre Meerts ( $\sim$ Pierre.Meerts@ulb.be)

Universite Libre de Bruxelles https://orcid.org/0000-0003-4215-027X

\section{Research Article}

Keywords: Tropical forest, Botanic gardens, Global Naturalized Alien Flora database (GloNAF), Global Register of Introduced and Invasive Species (GRIIS)

Posted Date: June 18th, 2021

DOI: https://doi.org/10.21203/rs.3.rs-516922/v1

License: (c) (i) This work is licensed under a Creative Commons Attribution 4.0 International License. Read Full License 


\section{Abstract}

The Democratic Republic of the Congo (D.R. Congo) represents a striking gap of knowledge on alien plant species. In this paper, we use digitised herbarium collections to assemble a checklist of alien plant species in D.R. Congo and to examine patterns in the alien flora. The new checklist comprises 426 alien species i.e., $182(42.5 \%)$ casuals, 244 (57.5\%) naturalised of which 80 (19\% of aliens) are invasive. Discrepancies with previous databases are discussed. For many species in previous databases, we failed to find evidence for occurrence outside cultivation. A total of 158 taxa were not included in previous lists, 44 of which are new to D.R. Congo. Considering the size of the country and its rich native flora, the alien flora of D.R. Congo does not appear to be species rich. The alien flora is particularly rich in Fabaceae $(15 \%)$ and in annual species (36\%). America is by far the most important source continent (65\%) and the proportion of annuals of American origin is particularly large among the most widespread species. Invasive success is discussed in terms of residence time. The very low number of new species records after 1960 is most likely accounted for by decreasing sampling effort. The results illustrate how herbarium collections can be used to critically revise existing checklists of alien species in tropical Africa. Field work is urgently needed to improve coverage of recent introductions and to monitor the status of alien species, especially in protected areas and around botanic gardens.

\section{Introduction}

Alien organisms represent an ever-increasing proportion of the biota worldwide and alien plant invasions have become a "hot topic" in biodiversity research (van Kleunen et al. 2015; Pyšek et al. 2017; Seebens et al. 2018). Tropical Africa is a major area for plant diversity (Küper et al. 2005; Sosef et al. 2017) and alien plant species could represent a serious threat (Stadler et al. 2000; Obiri 2011; Boy and Witt 2013; Foxcroft et al. 2013). However, with the notable exception of South Africa (Richardson et al. 2020), sub-Saharan Africa lags far behind for research on alien species (Pyšek et al. 2008; Turbelin et al. 2017; Essl et al. 2019).

Compiling alien flora inventories is an essential step to initiate monitoring and assess the impact of alien species (Hamer et al. 2012; Pyšek et al. 2004; Randall et al. 2008; Groom et al. 2015; Latombe et al. 2017). Many tropical African countries suffer from a lack of alien species inventories despite recent efforts to fill this gap of knowledge (e.g., Maroyi 2012; Rejmánek et al. 2016; Witt et al. 2018; Ansong et al. 2019). Some recent national flora checklists incorporate information on introduced species (Figueiredo and Smith 2008; Phiri 2005; Mapaura and Timberlake 2004), as does the African Plants database (https://www.ville-ge.ch/musinfo/bd/cjb/africa/index.php?langue=an). In the last decade, considerable effort to synthesize information and to assemble regional and global checklists of alien plant species has been made under the impulsion of different actors (Groom et al. 2015). Two large, open-source databases have been produced, i.e., the Global Register of Introduced and Invasive Species (GRIIS) assembled by IUCN Invasive Species Specialist Group and hosted by GBIF (https://www.gbif.org) (Pagad et al. 2018), and the Global Naturalized Alien Flora database (GloNAF) (van Kleunen et al. 2019). These inventories are rapidly gaining popularity to analyse patterns in alien plant invasion at regional or 
global scale (Randall 2017; Turbelin et al 2017; Essl et al. 2019). However, for sub-Saharan Africa, they are often incomplete and suffer from taxonomic and biogeographic uncertainties (Ansong et al. 2019; Meyer et al. 2016; McGeoch and Jetz 2019).

The Democratic Republic of the Congo (further D.R. Congo) represents a striking gap of knowledge on alien plant species. D.R. Congo hosts ca. 11,000 native species with 18.3\% endemism (Pyšek et al. 2017; Sosef et al. 2017). However, information on alien plant species in D.R. Congo is extremely scarce, with very few case studies (Zachariades et al. 2013; Useni Sikuzani et al. 2018; Mbale et al. 2019). Based on GLoNAF database, Pyšek et al. (2017) reported 522 naturalised species of seed plants in D.R. Congo, i.e., $4.5 \%$ of the total flora. Recently, we explored patterns in the alien flora D.R. Congo for the first time (Bordbar and Meerts 2020). During the preparation of that work, it appeared that databases of alien species in D.R. Congo suffered from several shortcomings.

During the last decade, research on the flora of D.R. Congo has received strong impetus under leadership of Meise Botanic Garden (Belgium), with important progress in the production of the Flore d'Afrique centrale (Sosef 2016). At the same time, digitisation of the rich plant collections from D.R. Congo in BR has made a huge amount of materials easily available and searchable through a user-friendly portal (Vissers et al. 2017) (http://www.botanicalcollections.be/). Other digitised specimens are available through the GBIF portal (https://www.gbif.org). Digitisation of herbarium collections greatly facilitates access to information and opens exciting new research possibilities (Stropp et al. 2016; Soltis 2017; James et al. 2018). Herbarium collections have been successfully used to assemble alien species checklists (Stadler et al. 1998; Crawford and Hoaglan 2009; Fuentes et al. 2013, Maroyi 2012).

In this paper, we use digitised herbarium collections to assemble a new checklist of alien plant species in D.R. Congo. First, based on herbarium specimens, all records in GLoNAF and GRIIS lists are checked for effective presence outside cultivation in D.R. Congo, geographic distribution, and date of first record. Secondly, based on extensive data mining from digitised collections, we systematically tracked species not recorded in either list. Based on the new list, we provide the first comprehensive overview of the alien flora of D.R. Congo, in terms of phytogeographic origin, taxonomic assemblage, life forms, date of first record and occurrence.

\section{Materials And Methods}

Study area

The Democratic Republic of the Congo covers 2,345,409 $\mathrm{km}^{2}$ in Central Africa, spanning from $13^{\circ} \mathrm{S}$ to $5^{\circ} \mathrm{N}$ (altitude range: $0-5110 \mathrm{~m}$ ). Its population is ca. 86 million. D.R. Congo was governed by the king of Belgium since 1885 and was a Belgian colony from 1909 to 1960. D.R. Congo has proportionally fewer paved highways than any country in Africa and its nominal GDP per capita is one of the lowest in the world (Herderschee et al. 2012). Agriculture is the largest sector in economy with 10 million ha cultivated (FAO 2013). D.R. Congo comprises $18 \%$ of the world's tropical forests, but the Congo Basin is subjected to 
steadily increasing human influence due to deforestation and urbanisation (Anonymous 2012; Potapov et al. 2013), which could favour the expansion of non-native species (Essl et al. 2019).

D.R. Congo harbours at least five types of climate (according to the Köppen classification; Peel et al. 2007) i.e., tropical rain forest (Af), tropical monsoon (Am), tropical wet and dry (Aw), temperate with dry winter and hot summer (Cwa), temperate with dry winter and warm summer (Cwb). The vegetation of D.R. Congo is highly diversified depending on climate and phytogeographic context, including GuineoCongolian rainforest, Zambezian dry tropical woodlands and grasslands, afromontane and afroalpine communities (White 1983). Robyns (1948) divided D.R. Congo into 10 phytogeographic districts, based on vegetation and flora. Although this phytogeographic system is no longer fully satisfying, it is still in use in floristic publications because herbarium collections are managed according to it.

The most important source of floristic information for D.R. Congo is the Flore d'Afrique centrale (1948-) (hereafter FAC), in production since 1948, still incomplete (Sosef 2016). FAC now covers ca. $70 \%$ of the estimated 11.000 vascular plants in D.R. Congo. FAC includes both native and introduced species. Other important floras and catalogues, with narrower geographic coverage, include Robyns (1947), Robyns and Tournay (1955), Troupin (1956), Pauwels (1993), and Lejoly et al. (2010).

Data assemblage; effective presence in D.R. Congo

Species considered in this work are alien species that have been observed outside cultivation in D.R. Congo. This definition includes casual, naturalised (= established), and invasive species following the definition of Richardson et al. (2000, 2011), Pyšek et al. (2004) and Blackburn et al. (2011). The Global Register of Introduced and Invasive Species (GRIIS, http://www.griis.org) (Pagad et al. 2018) comprises 397 alien seed plants for D.R. Congo (Groom et al. 2020). The GloNAF database, in principle limited to naturalised species, comprises 522 entries for D.R. Congo. Other online database and information facilities have been explored for additional species, in particular the World Checklist of Selected Plant families (WCSP 2014) (https://wcsp.science.kew.org), Plants of the World Online (Kew) (www.plantsoftheworldonline.org) (POWO), and the African Plant Database (APD) (www.villege.ch/musinfo/bd/cjb/africa/recherche.php).

The floristic and phytosociological literature has been extensively searched for additional alien species. Published volumes of FAC since 1948 (partly available online: www.floredafriquecentrale.be) have been searched extensively. Other important sources were Pauwels (2014), and Lejoly et al. (2010). Checklists of alien species in neighbouring countries have been mined to orient herbarium collection search for more species (Ansong et al. 2019; Bigirimana 2011; Mapaura and Timberlake 2004; Maroyi 2012; Noba et al. 2017; Phiri 2005; Rejmánek et al. 2016; Anonymous 2016; Witt et al. 2018).

All entries, both from GRIIS and GLoNAF lists, and additional species from all other sources, were checked for effective presence in D.R. Congo. Effective presence is testified by a specimen in a collection. The most important collection for D.R. Congo is BR (www.botanicalcollections.be). Specimens in other collections were retrieved by GBIF. Literature records not supported by material evidence cannot be 
checked for taxonomic correctness and were therefore excluded. Very few exceptions were accepted i.e., when an herbarium specimen not seen by us is cited in a taxonomic publication, verified by an expert. The accepted names follow the APD, or POWO for taxa not covered in the former reference.

Presence outside cultivation

Herbarium labels have been systematically screened for locality and habitat information. First, presence outside cultivation has been verified by exhaustive screening of collecting information recorded. Specimens collected from cultivated plants have been discarded (herbarium label explicitly mentioning "cultivé/cultivated", "planté/planted", "introduit/introduced"). Collections made in botanical gardens (Kisantu, Eala, University of Kisangani), arboreta (L'Etoile at Lubumbashi), and agronomic research stations of INEAC (Yangambi, etc.) have also been discarded, unless the collecting information on the label clearly indicated that the specimen was taken from a plant escaped from cultivation ("subspontané/ spontaneous", "échappé/escaped", "naturalisé/naturalised", "envahissant/invasive"). Any species reported by FAC as "subspontané" (i.e., escaped) or naturalised has been included.

Alien vs. native species; region of origin

Criteria defined by Essl et al. (2018) have been used to check alien status. For many species with pantropical and Afro-American distribution, the native range is often difficult to determine (Alpern et al. 2008; Essl et al. 2019; Chevalier 1931, 1951; Wild 1978). American species have been introduced to Africa by transatlantic navigation well before colonisation of Africa by Europeans (Alpern et al. 2008; Wild 1978; Gallagher 2016).

We have used different sources of information to assess the status of species in D.R. Congo, i.e., POWO, APD, FAC, Flora Zambesiaca and Flora of Tropical east Africa. We have generally accepted the status proposed by the majority of these sources. When the status was unclear e.g., when different sources give contradictory information (disregarding obvious material errors), the species has been included in the list as "cryptogenic" (Pagad et al. 2018).

Naturalisation and invasiveness

A preliminary attempt was made to assign each species to a particular stage in the invasion process. Naturalised species are those that form self-replacing populations independently of direct human intervention (Richardson et al. 2000, 2011; Blackburn et al. 2011). First, we have considered as naturalised, any species previously reported as such in FAC, or other published floristic and vegetation studies, acknowledging that naturalisation can be effective only locally. Second, we have accepted as being naturalised species fulfilling at least one of the following criteria: i) represented by large numbers of specimens in collections, ii) not restricted to anthropogenic habitats, iii) collected repeatedly from the same locality or the same region over an extended period.

Other aliens are referred to as "casuals". These comprise both deliberately introduced species occasionally escaping from cultivation but not maintaining self-sustainable populations and 
unintentionally introduced species observed as isolated specimen mostly in anthropogenic habitats.

Naturalised species have been assessed for invasiveness, based on Richardson et al. (2000) criteria i.e., "invasive species are a subset of naturalised species that produce reproductive offspring often in very large numbers at considerable distances from the parents and/or site of introduction, and have the potential to spread over long distances". Our assessment is based on previous reports in the literature, and on the number of specimens in collection. However, this criterion must be considered with caution because some species which have experienced recent and/or regional expansion are often underrepresented in collections.

Life form

Life form, (i.e., annual herbaceous, perennial herbaceous, tree, shrub, climber and aquatic), and region of origin were obtained from floras and POWO.

Number of specimens

The number of specimens in collections has been counted. Residence time in D.R. Congo was estimated from the collecting date of the earliest specimen in collections (Ahern et al. 2010). We have examined if the number of specimens in collections is correlated to the residence time.

Occurrence and distribution within D.R. Congo

Based on locality data on specimen label, species occurrence in the different phytogeographic regions of D.R. Congo was determined.

The data were analysed using Microsoft Office Excel 2016, PAST v.3.25 (Hammer et al. 2001).

\section{Results}

\section{Results}

Our revised checklist of alien seed plants in D.R. Congo (Supplementary Information S1) includes 426 species i.e., 182 casuals (42.5\%), 244 naturalised (57.5\%) of which $80(19 \%)$ are invasive. These are represented by ca. 20,000 specimens in collections. The 20 most abundant species are listed in Table 1 . The precise identity of a few taxa is uncertain (Bellucia cf. pentamera, Cecropia cf. pachystachya, Gnaphalium cf. pensylvanicum, Taraxacum sp., Vicia sativa s.I.)) and further taxonomic work is needed.

Table 2 compares the revised checklist with previous databases. Only 194 out of 397 species in GRIIS list and 254 of 522 species in GLoNAF list are confirmed as alien species occurring outside cultivation in D.R. Congo. Many species in previous databases have been excluded for different reasons. First, for a total of 168 species (149 species in GRIIS and 159 species in GLoNAF), all specimens in collections appear to have been collected in botanic gardens, agronomic experimental stations, amenity gardens or otherwise cultivated specimens (Supplementary Information S2). BR collections comprise quite many specimens 
collected in the botanic gardens of Kisantu and Eala. For a few of these, however, collecting information indicates that the species has escaped from cultivation in the garden, and these have been accepted in our list. Secondly, a total of 88 species in previous databases are native to D.R. Congo (28 in GRIIS, 83 in GloNAF) (Supplementary Information S3). For 12 species, the native range is not known with certainty and these have been accepted in the introduced list as "cryptogenic" (Supplementary Information S1).

Thirdly, for 36 taxa, there is no material evidence for occurrence in D.R. Congo, and previous records were likely based on material errors, including wrongly geolocalised specimens, or specimens from neighbouring countries (Rwanda and Burundi), or misidentification (Supplementary Information S4).

230 species in our list were not recorded in GRIIS, and 169 not in GLoNAF, and 158 species are reported in neither list. However, not all of these are new to the alien flora of D.R. Congo because many had previously been reported as alien in D.R. Congo by POWO and/or the FAC. Forty-four species had never been reported in D.R. Congo hitherto, of which 13 are naturalised (Supplementary Information S5).

Taxonomic assemblage

Seventy-six families are represented among aliens. The five most species-rich families are Fabaceae (65 species, 15\%), Asteraceae (47, 11\%), Solanaceae (40, 9\%), Poaceae (36, 8\%) and Amaranthaceae $(20,5 \%)$ comprising together almost $50 \%$ of alien species (Fig. 1). The proportion of naturalised species is larger in Asteraceae compared to the whole alien flora (70\% vs $57.5 \%$ ); the proportions of invasive species vary among the top 5 families with Asteraceae (16 invasive species i.e., $34 \%$ of all introduced Asteraceae) much overrepresented among invasive species (30\%) i.e., a much larger proportion than in the whole alien flora (19\% invasive). The most species-rich genera are Solanum (19 species), Ipomoea (11), Senna (10), Euphorbia (8), Amaranthus (8), Paspalum (7) (Supplementary Information S1).

\section{Life forms}

Annual herbaceous species are the most frequent life form (158 species, 37\%), followed by perennial herbaceous (94 species, 22\%) (Fig. 2). The proportions of naturalised + invasive vary significantly among life forms $\left(X^{2}{ }_{\text {obs }}=24.121\right.$, d.f. $\left.=10, P<0.01\right)$ being markedly larger for annual herbaceous $(60 \%)$ and perennial herbaceous (63\%) species compared to trees and shrubs ( $47 \%$ together). Aquatic species (12) comprise the smallest group.

Phytogeographic assemblage

The Americas are by far the most frequent source continent (65\%), far ahead of all other continents (Fig. 3). The proportion of naturalised and invasive species varies among source continents $\left(\chi^{2}\right.$ obs $=$ 38.73 , d.f. $=10, P<0.001)$. $27 \%$ of American aliens in D.R. Congo are invasive i.e., a much larger proportion than for all other origins (5\%). Seventy-five invasive species in D.R. Congo are from the Americas vs. only 8 invasive aliens from other regions.

Number of specimens and earliest record date 
The number of specimens in collection ranges from 1 to 553 (Ageratum conyzaeoides). The earliest collection date is 1869 (Schwenckia americana) and the most recent new record is 2010 (Stachytarpheta cayennensis) (Supplementary Information S1). The number of specimens increases significantly with time since first record (Fig. 4). When controlling for time, invasive species tend to have larger numbers of specimens compared to the rest of aliens.

The cumulated number of species has increased regularly in the first half of the 20th century, reaching a plateau after 1960 (Fig. 5). As few as 31 new species have been added to the alien flora after 1960.

Distribution within D.R. Congo

Specimens in collections provide the only reliable, verifiable evidence for effective presence and status (cultivated/wild) in D.R. Congo. A substantial number of records in previous lists are not supported by voucher materials. A few of these are material errors, including specimens collected in neighbouring countries (Burundi, Rwanda). Due to specimen mislabelling, several species have long been included in the flora of D.R. Congo while they were in fact collected in China (Robbrecht et al. 2021). Specimens in collection allowed us to detect several identification errors and wrong geolocalisation (Supplementary Information S4). Quite a few native species were also included in error in previous lists (Supplementary Information S3).

Our new list comprises many species that were not included in previous databases. Not all of these, however, represent additions to the alien flora of D.R. Congo, because they were already recorded as alien in D.R. Congo in Plants of the World Online. Extensive data mining from collections guided by literature search has allowed us to uncover forty-four species that had never been reported for D.R. Congo hitherto (Supplementary Information S5).

Alien species richness

Based on the 522 naturalised species in GloNAF Pyšek et al. (2017) estimated the proportion of alien species in the flora of D.R. Congo to be $4.5 \%$. Based on our revised checklist, the proportion of naturalised species is $2.3 \%$ (3.9\% when including casuals). The naturalised flora of D.R. Congo appears to be relatively species-poor, in comparison to global patterns. Based on the species richness - area relationship in Pyšek et al. (2017), the expected number of naturalised species in D.R. Congo is ca. 1000 species i.e., four-fold the actual number (two-fold when including casuals). Second, based on the correlation between species richness in the alien and the native flora (Pyšek et al. 2017), the expected number of naturalised species is 457 species (for 11,000 native species), higher than the actual number (244), even when including casuals (425). D.R. Congo is obviously not a hotspot of alien species richness. These figures fit in well with the generally low alien species richness in tropical regions (Fine 2002). Higher intrinsic resistance of tropical ecosystems could be due to "fewer available free ecological niches, faster recovery of vegetation after disturbance or a lower introduction rate" (van Kleunen et al. 2015). Factors accounting for relatively low number of invasive species in African savannas were 
discussed by Foxcroft et al. (2010). The low level of economic development and the poor transport infrastructure in D.R. Congo are certainly also limiting factors (Essl et al. 2019).

However, our alien list is likely conservative for different reasons. First, some species, represented in collections only as specimens from cultivation, may actually also exist as garden escapes. Botanic gardens potentially represent important sources of alien plant introduction, especially in the tropics (Dawson et al. 2008). Naturalisation from botanic gardens in D.R. Congo has been circumstantially reported (Kembelo 1996; Binggeli 2011). Field observations in Congolese botanic gardens and neighbouring areas could reveal many more naturalised species than accepted here. Second, herbarium collections have poor coverage of recent decades, a well-known sampling bias in central Africa (Meyer et al. 2016). The cumulated number of alien species shows a plateau in the last three decades (Fig. 5), with very few additions after 1960, most likely due to decreasing sampling effort. The same pattern of saturation was previously found for Ghana and Zimbabwe (Ansong et al. 2019; Maroyi 2012). This contrasts with the lack of saturation in the accumulation of alien species worldwide (Seebens et al. 2016). Species recently introduced in D.R. Congo are certainly underrepresented in collections and new collecting efforts should be encouraged.

Native vs. alien; naturalisation and invasiveness

Our assessment of naturalisation is likely conservative. Evidence for naturalisation cannot be derived from herbarium specimens. Specimen number is not always a reliable indicator of naturalisation success, because a species can be naturalised only locally. Several alien species appear to have naturalised in botanic gardens, from which they have expanded to neighbouring regions (Musa acuminata, Cecropia sp., Rivina humilis, Petiveria alliacea ...). On the other hand, some species represented by large number of specimens in collections are still not considered as naturalised by recent floras e.g., Solanum aethiopicum (Bikandu et al. 2020). Interestingly, a few species that were explicitly reported as being naturalised locally have not been collected for a very long time (e.g., Musa acuminata in Yangambi), suggesting that such species have gone extinct or have failed to spread from their naturalised population. On the contrary, other species naturalised in botanic gardens, have spread quickly to neighbouring regions (e.g., Cecropia cf. pachystachya in the region of Eala (Hauman 1948)). The (past and present) role of botanic gardens in the introduction of alien species in D.R. Congo deserves further investigation.

In contrast to the relatively low number of alien species, the number of invasive species (80) appears to be quite high in comparison to expectations based on the number of naturalised species (21). This could be due to our too inclusive criterion used in this work. However, our estimation is remarkably close to the 84 invasive species in Zimbabwe (Maroyi 2012). Interestingly, most of the species considered here as invasive were already recorded in D.R. Congo over a century ago. This suggests that long residence time is a most important determinant of invasiveness (Ahern et al. 2010; Philips et al. 2010). However, when controlling for time since first record, invasive species tend to have more specimens in collections. This 
could indicate that these species indeed have a higher spread rate, or, alternatively, that they were introduced long before the first specimen was collected.

Taxonomic, phytogeographic and life form spectrum

Patterns in the alien flora of D.R. Congo are compared with the global patterns (Pyšek et al. 2017) and with regional patterns in two other sub-Saharan countries i.e., Ghana, in the Guineo-Congolian region (Ansong et al. 2019) and Zimbabwe in the Zambezian region (Maroyi 2012) (Table 3). The alien flora is richer in Fabaceae (17\%) and poorer in Poaceae (9\%) than global patterns. A prominent contribution of Fabaceae was also found in Ghana by Ansong et al. (2019). The large contribution of Solanaceae (ranking $3 d, 9 \%$ of aliens) is a striking feature of the alien flora. Many Solanaceae species have been introduced to D.R. Congo as edible plants (leaves and/or fruits) and have often escaped from cultivation (Bikandu et al. 2020). However, in terms of invasive species, Asteraceae stand out with 16 species, most likely due to their relatively high dispersal capacity (anemochory).

Concerning life forms, the contribution of annuals (38\%) is markedly higher than global patterns $(23 \%)$ and very similar to Zimbabwe (37\%); in Ghana, the bias towards to annuals is much less marked (Table 3). Trees and shrubs comprise $22 \%$ of aliens, very similar to Zimbabwe. The large contribution of annuals in Zimbabwe and D.R. Congo could be accounted for by the long dry season in the Zambezian ecoregion (southern D.R. Congo). The bias towards annuals is even more striking for invasive species, with 42 invasive annuals vs. only 15 invasive trees and shrubs. However, as pointed out by Bordbar and Meerts (2020), life history patterns are strongly family-specific in the alien flora of D.R. Congo, with trees and shrubs much overrepresented among alien Fabaceae, and annuals much overrepresented among alien Asteraceae, reflecting contrasting introduction pathways (i.e., deliberate introduction for forestry purposes for Fabaceae, vs. accidental introduction of weeds for Asteraceae).

Concerning the region of origin, the overwhelming contribution of the Americas (65\%), much larger compared to the global scale (30\%) is in line with Ghana and Zimbabwe. This is accounted for by a long history of transatlantic exchanges of crops (and contaminant seed) between Africa and the Americas, dating back to the 16th century (Wild 1978) and possibly even earlier (Gallagher 2016). The Americas are even more overrepresented among the most widespread species (Table 1) and among invasive species (Fig. 3), as found in Ghana.

Considering the history of European colonisation, the virtual lack of European species is striking, as previously found in Ghana (Ansong et al. 2019). Climatic mismatch is likely the cause. This hypothesis is supported by the observation that quite a few cryptogenic species with a mostly temperate distribution, occur in D.R. Congo only at high elevation (Afromontane belt in the Albertine Rift.). Whether such populations are native or were introduced by humans is difficult to ascertain without evidence from molecular markers. Some of these mostly high-altitude species in D.R. Congo also have ruderal populations at lower elevation (e.g., Poa annua), certainly of recent anthropogenic origin. Such species are therefore accepted as aliens, as recommended by Pagad et al. (2018). 


\section{Conclusions}

Massive digitisation and online release of images of herbarium specimens offers excellent opportunities to improve checklists of alien species in tropical Africa. For D.R. Congo, many previous records are not confirmed by voucher materials collected outside cultivation and should be deleted from existing checklists. Conversely, extensive search in online collections made it possible to discover many previously unknown species for the alien flora of D.R. Congo.

The alien flora of D.R. Congo is relatively species-poor considering the large area of the country and its rich native flora. The overwhelming contribution of American species, of annual Asteraceae, woody Fabaceae, Solanaceae are striking features of the alien flora.

Field work is urgently needed to assess the status of many alien species, and to ensure better coverage of recent introductions. Botanical gardens and protected nature areas are priority targets in this research agenda.

\section{Declarations}

\section{Funding}

No funding was received for conducting this study

\section{Conflicts of interest/Competing interests}

The authors have no conflicts of interest to declare that are relevant to the content of this article

\section{Availability of data and material}

All data are available in Supplementary Information

\section{Code availability}

Not applicable

\section{Authors' contributions}

FB assembled the checklist and analysed the data; PM designed the research, contributed to checklist validation, and wrote the manuscript.

\section{Ethics approval}

Not applicable

\section{Consent to participate}


Not applicable

\section{Consent for publication}

Not applicable

\section{References}

1. African Plants Database (version 3.3.5) Conservatoire et Jardin botaniques de la Ville de Genève and South African National Biodiversity Institute, Pretoria. Available from: http://www.villege.ch/musinfo/bd/cjb/africa/index.php?langue=an (accessed 30th March 2021)

2. Ahern RG, Landis DA, Reznicek AA, Schemske DW (2010) Spread of exotic plants in the landscape: the role of time, growth habit, and history of invasiveness. Biol Invasions 12:3157-3169. https://doi.org/10.1007/s10530-010-9707-x

3. Alpern SA (2008) Exotic plants of Western Africa: where they came from and when. History in Africa 35:63-102

4. Anonymous (2012) Synthèse des études sur les causes de la déforestation et de la dégradation des forêts en République Démocratique du Congo. Ministère de l'environnement, Conservation de la Nature et Tourisme, UN-reDD Programme, Kinshasa

5. Anonymous (2016) Study to assess the impacts of invasive alien species (Flowering plants, fish and insects) in natural forests, agro-ecosystems, lakes and wetland ecosystems in Rwanda and develop their management plans. Rwanda Environment Management Authority, Kigali

6. Ansong M, Pergl J, Essl F, Hejda M, van Kleunen M, Randall R, Pyšek P (2019) Naturalized and invasive alien flora of Ghana. Biol Invasions 21(3):669-683. https://doi.org/10.1007/s10530-0181860-7

7. Bigirimana J, Bogaert J, De Cannière C, Lejoly J, Parmentier I (2011) Alien plants dominate the vegetation in a city of Sub-Saharan Africa. Landscape Urban Planning 100:251-267

8. Bikandu B, Lukoki F, Habari JP, Ntore S, Sosef M (2020) Solanaceae. In: Sosef M (ed) Flore d'Afrique centrale (République démocratique du Congo, Rwanda, Burundi), nouvelle série. Jardin botanique, Meise

9. Binggeli P (2011) The human dimensions of invasive plants in tropical Africa. In: Rotherham ID, Lambert R (eds) Invasive and introduced plants and animals: human perceptions, attitudes and approaches to management. Earthscan, Abingdon, pp 201-220

10. Blackburn TM, Pyšek P, Bacher S, Carlton JT, Duncan RP, Jaros V, Wilson JRU, Richardson DM (2011) A proposed unified framework for biological invasions. Trends Ecol Evol 26(7):333-339. https://doi.org/10.1016/j.tree.2011.03.023

11. Bordbar F, Meerts P (2020) Patterns in the alien flora of the Democratic Republic of the Congo: a comparison of Asteraceae and Fabaceae. Plant Ecol Evol 153(3):373-389. https://doi.org/10.5091/plecevo.2020.1754 
12. Boy G, Witt A (2013) Invasive alien plants and their management in Africa. Gutenberg Press Limited, Malta

13. Chevalier A (1931) Le rôle de l'Homme dans la dispersion des plantes tropicales. Échanges d'espèces entre l'Afrique Tropicale et l'Amérique du Sud. Revue de botanique appliquée et d'agriculture coloniale 120:633-650

14. Chevalier A (1951) Mauvaises herbes envahissantes, fléaux redoutables pour l'Agriculture en Afrique tropicale. Revue internationale de botanique appliquée et d'agriculture tropicale 345-346:390-399

15. Crawford PHC, Hoagland BW (2009) Can herbarium records be used to map alien species invasion and native species expansion over the past 100 years? J Biogeogr 36:651-661. https://doi.org/10.1111/j.1365-2699.2008.02043.x

16. Dawson W, Mndolwa AS, Burslem DFRP, Hulme PE (2008) Assessing the risks of plant invasions arising from collections in tropical botanical gardens. Biodivers Conserv (2008) 17:1979-1995. DOI 10.1007/s10531-008-9345-0

17. EssI F, Bacher S, Genovesi P, Hulme PE, Jeschke JM, Katsanevakis S, Kowarik I, Kühn I, Pyšek P, Rabitsch W, Schindler S, van Kleunen M, Vila M, Wilson JRU, Richardson DM (2018) Which taxa are alien? Criteria, applications, and uncertainties. Bioscience 68:496-509

18. Essl F, Dawson W, Kreft H, Pergl J, Pyšek P et al (2019) Drivers of the relative richness of naturalized and invasive plant species on Earth. AoB PLANTS 11:plz051. https://doi.org/10.1093/aobpla/plz051

19. FAO (2013) Democratic Republic of the Congo - BEFS country brief. FAO, Rome

20. Figueiredo E, Smith G (2008) Plants of Angola / Plantas de Angola. Strelitzia 22. South African National Biodiversity Institute, Pretoria

21. Fine PVA (2002) The invasibility of tropical forests by exotic plants. J Trop Ecol 18:687-705

22. Flore d'Afrique Centrale (1948-) Published with different titles: Flore du Congo belge et RuandaUrundi (1948-1963) Spermatophytes. Vols. 1-10. Bruxelles, Institut national pour l'étude agronomique du Congo; Flore du Congo, du Rwanda et du Burundi, Spermatophytes (30 fasc., 19671971), \& Ptéridophytes (7 fasc., 1969-1971); Flore d'Afrique Centrale (Zaïre, Rwanda, Burundi), Spermatophytes (43 fasc., 1972-1996), \& Ptéridophytes (6 fasc., 1973-1993); since 1999, Flore d'Afrique Centrale (Congo-Kinshasa, Rwanda \& Burundi), Spermatophytes \& Ptéridophytes. Jardin Botanique National de Belgique, Meise

23. Foxcroft LC, Richardson DM, Rejmanek M, Pyšek $P$ (2010) Alien plant invasions in tropical and subtropical savannas: patterns, processes and prospects. Biol Invasions 12:3913-3933

24. Foxcroft LC, Witt A, Lotter WD (2013) Icons in peril: invasive alien plants in African protected areas. In: Foxcroft LC, Pyšek P, Richardson DM, Genovesi P (eds) Plant invasions in protected areas. Springer, Dordrecht, pp 117-144

25. Fuentes N, Pauchard A, Sánchez P, Esquivel J, Marticorena A (2013) A new comprehensive database of alien plant species in Chile based on herbarium records. Biol Invasions 15:847-858. http://dx.doi.org/10.1007/s10530-012-0334-6 
26. Gallagher D (2016) American plants in Sub-Saharan Africa: a review of the archaeological evidence. Azania: Archaeological Research in Africa 51(1):24-61

https://doi.org/10.1080/0067270X.2016.1150081

27. Groom Q, Desmet P, Vanderhoeven S, Adriaens T (2015) The importance of open data for invasive alien species research, policy and management. Management of Biological Invasions 6:119-125. http://dx.doi.org/10.3391/mbi.2015.6.2.02

28. Groom Q, Wong LJ, Pagad S (2020) Global Register of Introduced and Invasive Species - Democratic Republic of Congo. Version 1.4. Invasive Species Specialist Group ISSG. Checklist dataset https://doi.org/10.15468/vd6vcl accessed via GBIF.org on 2021-01-31

29. Hamer M, Victor J, Smith GF (2012) Best Practice Guide for Compiling, Maintaining and Disseminating National Species Checklists, version 1.0, released in October 2012. Copenhagen: Global Biodiversity Information Facility, 40 pp, ISBN: 87-92020-48-8, Accessible at http://www.gbif.org/orc/?doc_id=4752

30. Hammer $\emptyset$, Harper DAT, Ryan PD (2001) PAST: Paleontological Statistics Software Package for Education and Data Analysis. Palaeontologia Electronica 4(1): 9p. Version 3.25. Availhle at http://folk.uio.no/ohammer/past [accessed 1 Jan 2021]

31. Hauman L (1948) Moraceae. In: Boutique R (ed) Flore du Congo Belge et du Ruanda-Urundi, vol 1. I.N.É.A.C, Bruxelles, pp 52-175

32. Herderschee J, Kaiser K-A, Mukoko Samba D (2012) Resilience of an African Giant Boosting Growth and Development in the Democratic Republic of Congo. The World Bank, Washington DC

33. James SA, Soltis PS, Belbin L, Chapman AD, Nelson G, Paul DL, Collins M (2018) Herbarium data: Global biodiversity and societal botanical needs for novel research. Applications in Plant Sciences 6(2):e1024. https://doi.org/10.1002/aps3.1024

34. Kembelo K (1996) The botanical gardens of Zaire and the present state of biodiversity in Zaire. Bot Gard Conserv News 2:7

35. Klopper RR, Gautier L, Chatelain C, Smith GF, Spichiger R (2007) Floristics of the angiosperm flora of sub-Saharan Africa: an analysis of the African plant checklist and database. Taxon 56(1):201-208. https://doi.org/10.2307/25065751

36. Küper W, Sommer JH, Lovett JC, Mutke J, Linder HP, Beentje H, van Rompaey RASR, Chatelain C, Sosef M, Barthlott W (2005) Africa's hotspots of biodiversity redefined. Ann Mo Bot Gard 91:525-536

37. Latombe G, Pyšek P, Jeschke JM, Blackburn TM, Bacher S et al (2017) A vision for global monitoring of biological invasions. Biol Cons 213:295-308. https://doi.org/10.1016/j.biocon.2016.06.013

38. Lejoly J, Ndjele M-B, Geerinck D (2010) Catalogue-Flore des plantes vasculaires des districts de Kisangani et de la Tshopo (RD Congo). Ed 4. Taxonomania 30:1-307

39. Mapaura A, Timberlake J (eds) (2004) A checklist of Zimbabwean vascular plants. Southern African Botanical Diversity Network Report No. 33. SABONET, Pretoria

40. Maroyi A (2012) The casual, naturalised and invasive alien flora of Zimbabwe based on herbarium and literature records. Koedoe 54(1):1-6. https://doi.org/10.4102/koedoe.v54i1.1054 
41. Mbale HK, Mukendi MT, Bongo GN, Kikufi AB, Lukoki FL (2019) Floristic inventory of invasive alien aquatic plants found in some Congolese rivers, Kinshasa, Democratic Republic of the Congo. Asian J Environ Ecol 11(4):1-15. https://doi.org/10.9734/ajee/2019/v11i430142

42. McGeoch MA, Genovesi P, Bellingham PJ, Costello MJ, Mcgrannachan CM, Sheppard A (2016) Prioritizing species, pathways, and sites to achieve conservation targets for biological invasion. Biol Invasions 18:299-314. https://doi.org/10.1007/s10530-015-1013-1

43. McGeoch M, Jetz W (2019) Measure and Reduce the Harm Caused by Biological Invasions. One Earth 1, October 25, 2019. https://doi.org/10.1016/j.oneear.2019.10.003

44. Meyer C, Weigelt P, Kreft H (2016) Multidimensional biases, gaps and uncertainties in global plant occurrence information. Ecol Lett 19:992-1006. https://doi.org/10.1111/ele.12624

45. Noba K, Bassene C, Ngom A, Gueye M, Camara AA et al (2017) Invasive Plants of West Africa: Concepts, Overviews and Sustainable Management. Adv Recycling Waste Manag 2:121. DOI:10.4172/2475-7675.1000121

46. Obiri JF (2011) Invasive plant species and their disaster-effects in dry tropical forests and rangelands of Kenya and Tanzania. Journal of Disaster Risk Studies 3(2):417-428. https://doi.org/10.4102/jamba.v3i2.39

47. Pagad S, Genovesi P, Carnevali L, Schigel D, McGeoch MA (2018) Introducing the global register of introduced and invasive species. Scientific Data 5:170202. https://doi.org/10.1038/sdata.2017.202

48. Pauwels L (1993) Nzayilu N’ti. Guide des arbres et arbustes de la région de Kinshasa-Brazzaville. Jardin botanique national de Belgique, Meise

49. Pauwels L (2014) Cultivated and/or Exotic Plants in Central Africa (R.D. Congo - Rwanda - Burundi). URL: http://users.chello.be/cr28796/CultAfrC.htm

50. Peel MC, Finlayson BL, McMahon TA (2007) Updated world map of the Köppen-Geiger climate classification. Hydrol Earth Syst Sci 11:1633-1644. https://doi.org/10.5194/hess-11-1633-2007

51. Philips ML, Murray BR, Leishman MR, Ingram R (2010) The naturalization to invasion transition: Are there introduction-history correlates of invasiveness in exotic plants of Australia? Austral Ecol 35:695-703

52. Phiri PSM (2005) A checklist of Zambian vascular plants. Southern African Botanical Diversity Network Report No. 32. SABONET, Pretoria

53. Potapov PV, Turubanova SA, Hansen MC, Adusei B, Broich M, Altstatt A, Mane L, Justice CO (2013) Quantifying forest cover loss in Democratic Republic of the Congo, 2000-2010, with Landsat eTM + data. Remote Sens Environ 122:106-116. https://doi.org/10.1016/j.rse.2011.08.027

54. Pyšek P, Pergl J, Essl F, Lenzner B, Dawson W et al (2017) Naturalized alien flora of the world: species diversity, taxonomic and phylogenetic patterns, geographic distribution and global hotspots of plant invasion. Preslia 89:203-274. https://doi.org/10.23855/preslia.2017.203

55. Pyšek P, Richardson D, Rejmánek M, Webster G, Williamson M, Kirschner J (2004) Alien plants in checklists and floras: towards better communication between taxonomists and ecologists. Taxon 53(1):131-143. https://doi.org/10.2307/4135498 
56. Pyšek P, Richardson DM, Pergl J, Jarosík V, Sixtová Z, Weber E (2008) Geographical and taxonomic biases in invasion ecology. Trends Ecol Evol 23(5):237-244.

https://doi.org/10.1016/j.tree.2008.02.002

57. Randall JM, Morse LE, Benton N, Hiebert R, Lu S, Killeffer T (2008) The invasive species assessment protocol: a tool for creating regional and national lists of invasive nonnative plants that negatively impact biodiversity. Invasive Plant Science Management 1:36-49. https://doi.org/10.1614/IPSM-07020.1

58. Randall RP (2017) A global compendium of weeds. Ed.3. Perth. CABI

59. Rejmánek M, Huntley BJ, Le Roux JJ, Richardson DM (2016) A rapid survey of the invasive plant species in western Angola. Afr J Ecol 55:56-69

60. Richardson DM, Pyšek P, Rejmánek M, Barbour M, Panetta F, West C (2000) Naturalization and invasion of alien plants: concepts and definitions. Divers Distrib 6(2):93-107. https://doi.org/10.1046/j.1472-4642.2000.00083.x

61. Richardson DM, Pyšek P, Carlton JT (2011b) A compendium of essential concepts and terminology in biological invasions. In: Richardson DM (ed) Fifty years of invasion ecology: the legacy of Charles Elton. Blackwell Publishing, Oxford, pp 409-420

62. Richardson DM, Foxcroft LC, Latombe G, Le Maitre DC, Rouget M, Wilson JR (2020) The Biogeography of South African Terrestrial Plant Invasions. In: van Wilgen BW et al. (eds) Biological Invasions in South Africa, Invading Nature - Springer Series in Invasion Ecology 14, https://doi.org/10.1007/978-3-030-32394-3_3

63. Robbrecht E, De Smedt S, Goetghebeur P, Stoffelen P, Verloove F (2021) Four flowering plant species described from Katanga (D.R. Congo) are based on specimens collected in Guangxi, China. The H.A. Homblé collection in BR. Blumea 66:82-92

64. Robyns W (1947) Flore des Spermatophytes du Parc national Albert. II. Sympétales. Institut des Parcs Nationaux du Congo belge, Bruxelles

65. Robyns W (1948) Les territoires phytogéographiques du Congo belge et du Ruanda-Urundi. Atlas Général du Congo belge. Institut Royal Colonial Belge, Bruxelles

66. Robyns W, Tournay R (1955) Flore des Spermatophytes du Parc National Albert. III. Monocotylées. Bruxelles, Institut des Parcs nationaux du Congo belge

67. Seebens H, Blackburn TM, Dyer EE, Genovesi P, Hulme PE et al (2018) Global rise in emerging alien species results from increased accessibility of new source pools. Proc Natl Acad Sci USA 115(10):E2264-E2273. https://doi.org/10.1073/pnas.1719429115

68. Soltis PS (2017) Digitization of herbaria enables novel research. Am J Bot 104(9):1281-1284

69. Sosef MSM (2016) Producing the Floe d'Afrique centrale, past, present and future. Taxon 65:935939

70. Sosef MSM, Dauby G, Blach-Overgaard A, van der Burgt X, Catarino L et al (2017) Exploring the floristic diversity of tropical Africa. BMC Biol 15(1):15. https://doi.org/10.1186/s12915-017-0356-8 
71. Stadler J, Mungai G, Brandl R (1998) Weed invasion in East Africa: insights from herbarium records. Afr J Ecol 36:15-22. https://doi.org/10.1046/j.1365-2028.1998.115-89115.x

72. Stadler J, Trefflich A, Klotz S, Brandl R (2000) Exotic plant species invade diversity hot spots: the alien flora of northwestern Kenya. Ecography 23:169-176

73. Stropp J, Ladle RJ, Malhado ACM, Hortal J, Gaffuri J, Temperley WH, Skøien JO, Mayaux P. 2016 Mapping ignorance: 300 years of collecting flowering plants in Africa Global Ecology and Biogeography 25:1085-1096

74. Troupin G (1956) Flore des Spermatophytes du Parc National de la Garamba. I. Gymnospermes et Monocotylédones. Institut des Parcs Nationaux du Congo belge, Bruxelles

75. Turbelin AJ, Malamud BD, Francis RA (2017) Mapping the global state of invasive alien species: patterns of invasion and policy responses. Glob Ecol Biogeogr 26(1):78-92. https://doi.org/10.1111/geb.12517

76. Useni Sikuzani Y, Sambiéni Kouagou R, Maréchal J, llunga wa llunga E, Malaisse F, Bogaert J, Munyemba Kankumbi F (2018) Changes in the spatial pattern and ecological functionalities of green spaces in Lubumbashi (the Democratic Republic of Congo) in relation with the degree of urbanization. Tropical Conservation Science 11:1-17.

77. van Kleunen M, Dawson W, EssI F, Pergl J, Winter M et al (2015) Global exchange and accumulation of non-native plants. Nature 525(7567):100-103. https://doi.org/10.1038/nature14910

78. van Kleunen M, Pyšek P, Dawson W, Essl F, Kreft H et al (2019) The Global Naturalized Alien Flora (GloNAF) database. Ecology 100:e02542. https://doi.org/10.1002/ecy.2542

79. Vissers J, Bosch FV, Bogaerts A, Cocquyt C, Degreef J, Diagre D, de Haan M, De Smedt S, Engledow H, Ertz D, Fabri R, Godefroid S, Hanquart N, Mergen P, Ronse A, Sosef M, Stévart T, Stoffelen P, Vanderhoeven S, Groom Q (2017) Scientific user requirements for a herbarium data portal. PhytoKeys 78:37-57. https://doi.org/10.3897/ phytokeys.78.10936

80. WCSP (2014) World checklist of selected plant families. - Royal Botanical Gardens, Kew, URL: http://apps.kew.org/wcsp

81. White F (1983) Unesco/AETFAT/UNSO vegetation map of Africa. Scale 1: 5000000 (in colour). Unesco, Paris

82. Wild H (1978) Weeds and aliens in Africa: the American immigrant. University College of Rhodesia, Salisbury

83. Witt ABR, Beale T, Van Wilgen BW (2018) An assessment of the distribution and potential ecological impacts of invasive alien plant species in eastern Africa. Transactions of the Royal Society of South Africa 73(3):217-236. https://doi.org/10.1080/0035919X.2018.1529003

84. Zachariades C, van Rensburg SJ, Witt A (2013) Recent spread and new records of Chromolaena odorata in Africa. In: Zachariades C, Strathie LW, Day MD, Muniappan R (eds) Proceedings of the Eighth International Workshop on Biological Control and Management of Chromolaena odorata and other Eupatorieae. ARC-PPRI, Pretoria, pp 20-27 


\section{Tables}

Table 1

The 20 most abundant alien species in the flora of D.R. Congo

\begin{tabular}{|c|c|c|c|c|c|}
\hline Species & Family & $\begin{array}{l}\text { Number of } \\
\text { specimens }\end{array}$ & Life form & Origin & $\begin{array}{l}\text { Earliest } \\
\text { record }\end{array}$ \\
\hline Ageratum conyzoides L. & Asteraceae & 553 & Annual & America & 1888 \\
\hline Setaria sulcata Raddi & Poaceae & 444 & Perennial & America & 1879 \\
\hline Bidens pilosa L. & Asteraceae & 370 & Annual & America & 1888 \\
\hline Mimosa pigra L. & Fabaceae & 318 & Shrub & America & 1888 \\
\hline Erigeron bonariensis L. & Asteraceae & 288 & Annual & America & 1910 \\
\hline $\begin{array}{l}\text { Hilleria latifolia (Lam.) } \\
\text { H.Walter }\end{array}$ & Petiveriaceae & 281 & Perennial & America & 1895 \\
\hline $\begin{array}{l}\text { Alternanthera sessilis (L.) } \\
\text { R.Br. ex DC. }\end{array}$ & Amaranthaceae & 272 & Annual & Multiple & 1888 \\
\hline Eclipta prostrata (L.) L. & Asteraceae & 271 & Annual & America & 1888 \\
\hline Spermacoce pusilla Wall. & Rubiaceae & 265 & Annual & Asia & 1888 \\
\hline Hyptis lanceolata Poir. & Lamiaceae & 264 & Perennial & America & 1886 \\
\hline Physalis angulata L. & Solanaceae & 263 & Annual & America & 1887 \\
\hline Euphorbia hirta L. & Euphorbiaceae & 247 & Annual & America & 1888 \\
\hline Senna occidentalis (L.) Link & Fabaceae & 244 & Perennial & America & 1888 \\
\hline Sida cordifolia L. & Malvaceae & 243 & Annual & Multiple & 1886 \\
\hline $\begin{array}{l}\text { Paspalum } \\
\text { conjugatum P.J.Bergius }\end{array}$ & Poaceae & 231 & Perennial & America & 1888 \\
\hline Scoparia dulcis $\mathrm{L}$. & Plantaginaceae & 225 & Annual & America & 1888 \\
\hline Piper umbellatum L. & Piperaceae & 219 & Shrub & America & 1888 \\
\hline Amaranthus cruentus L. & Amaranthaceae & 216 & Annual & America & 1888 \\
\hline Oxalis corniculata L. & Oxalidaceae & 212 & Perennial & America & 1895 \\
\hline $\begin{array}{l}\text { Imperata cylindrica (L.) } \\
\text { P.Beauv. }\end{array}$ & Poaceae & 189 & Perennial & Multiple & 1888 \\
\hline
\end{tabular}


Table 2

Alien seed plants in D.R. Congo: Comparison of the new checklist with previous databases. GRIIS (Global Register of Introduced and Invasive Species); GloNAF (Global Naturalized Alien Flora database). Confirmed aliens: taxa in previous lists that are accepted in the new list; only in cultivation: alien taxa not found outside cultivation; native: taxa native to D.R. Congo; other taxa excluded: wrong identifications, geolocalisation errors, no specimen found, synonyms. New alien taxa: alien taxa collected outside cultivation, not included in previous databases

\begin{tabular}{|c|c|c|}
\hline & GRIIS & GloNAF \\
\hline Taxa included & 397 & 522 \\
\hline Confirmed aliens & 194 (108 naturalised) & 254 (151 naturalised) \\
\hline $\begin{array}{l}\text { Rejected taxa } \\
\text { Only in cultivation } \\
\text { Native } \\
\text { Other taxa excluded }\end{array}$ & $\begin{array}{l}149 \\
28 \\
27\end{array}$ & $\begin{array}{l}158 \\
83 \\
27\end{array}$ \\
\hline New alien taxa & 230 (136 naturalised) & 169 (93 naturalised) \\
\hline
\end{tabular}


Table 3

Patterns in the alien flora of D.R. Congo, compared with global patterns, and with two other sub-Saharan Africa countries (N: naturalised; A: alien; I: invasive: C: casual)

\begin{tabular}{|c|c|c|c|c|}
\hline & $\begin{array}{l}\text { Global } \\
\text { Pyšek et al. } \\
\text { (2017) }\end{array}$ & $\begin{array}{l}\text { Zimbabwe } \\
\text { Maroyi } \\
(2012)\end{array}$ & $\begin{array}{l}\text { Ghana } \\
\text { Ansong et al. } \\
(2019)\end{array}$ & $\begin{array}{l}\text { D.R. Congo } \\
\text { (This } \\
\text { work) }\end{array}$ \\
\hline $\begin{array}{l}\text { Aliens (A) } \\
\text { Casuals (C) } \\
\text { Naturalised (N) Invasive } \\
(\mathrm{I})\end{array}$ & $13168 \mathrm{~N}$ & $\begin{array}{l}391 \mathrm{~A} \\
153 \mathrm{C} \\
154 \mathrm{~N} \\
84 \mathrm{I}\end{array}$ & $\begin{array}{l}- \\
\overline{2} \\
251 \mathrm{~N}\end{array}$ & $\begin{array}{l}426 \mathrm{~A} \\
182 \mathrm{C} \\
244 \mathrm{~N} \\
80 \mathrm{I}\end{array}$ \\
\hline Fabaceae & $9 \%$ & $13 \%$ & $22 \%$ & $15 \%$ \\
\hline Asteraceae & $10 \%$ & $14 \%$ & $8 \%$ & $11 \%$ \\
\hline Poaceae & $10 \%$ & $12 \%$ & $6 \%$ & $8 \%$ \\
\hline Annuals & $22 \%$ & $37 \%$ & $24 \%$ & $37 \%$ \\
\hline Herbaceous perennials & $39 \%$ & $24 \%$ & $25 \%$ & $22 \%$ \\
\hline Trees and shrubs & $32 \%$ & $21 \%$ & $40 \%$ & $27 \%$ \\
\hline Origin: America & $30 \%$ & $49.6 \%$ & $54 \%$ & $65 \%$ \\
\hline Origin: Asia & $32 \%$ & $23.8 \%$ & $28 \%$ & $17 \%$ \\
\hline Origin: Europe & $15 \%$ & $24 \%$ & $1 \%$ & $<1 \%$ \\
\hline \multicolumn{5}{|c|}{$\begin{array}{l}\text { Figures } \\
\text { Click here to download actual image }\end{array}$} \\
\hline \multicolumn{5}{|c|}{ Click here to download actual image } \\
\hline \multicolumn{5}{|c|}{ Click here to download actual image } \\
\hline \multicolumn{5}{|c|}{$\begin{array}{l}\text { Click here to download actual image } \\
\text { Fig } 3 \text { Phytogeographic spectrum of the alien flora of D.R. Congo }\end{array}$} \\
\hline \multicolumn{5}{|c|}{ Click here to download actual image } \\
\hline Click here to download & tual image & & & \\
\hline
\end{tabular}

\section{Figures}




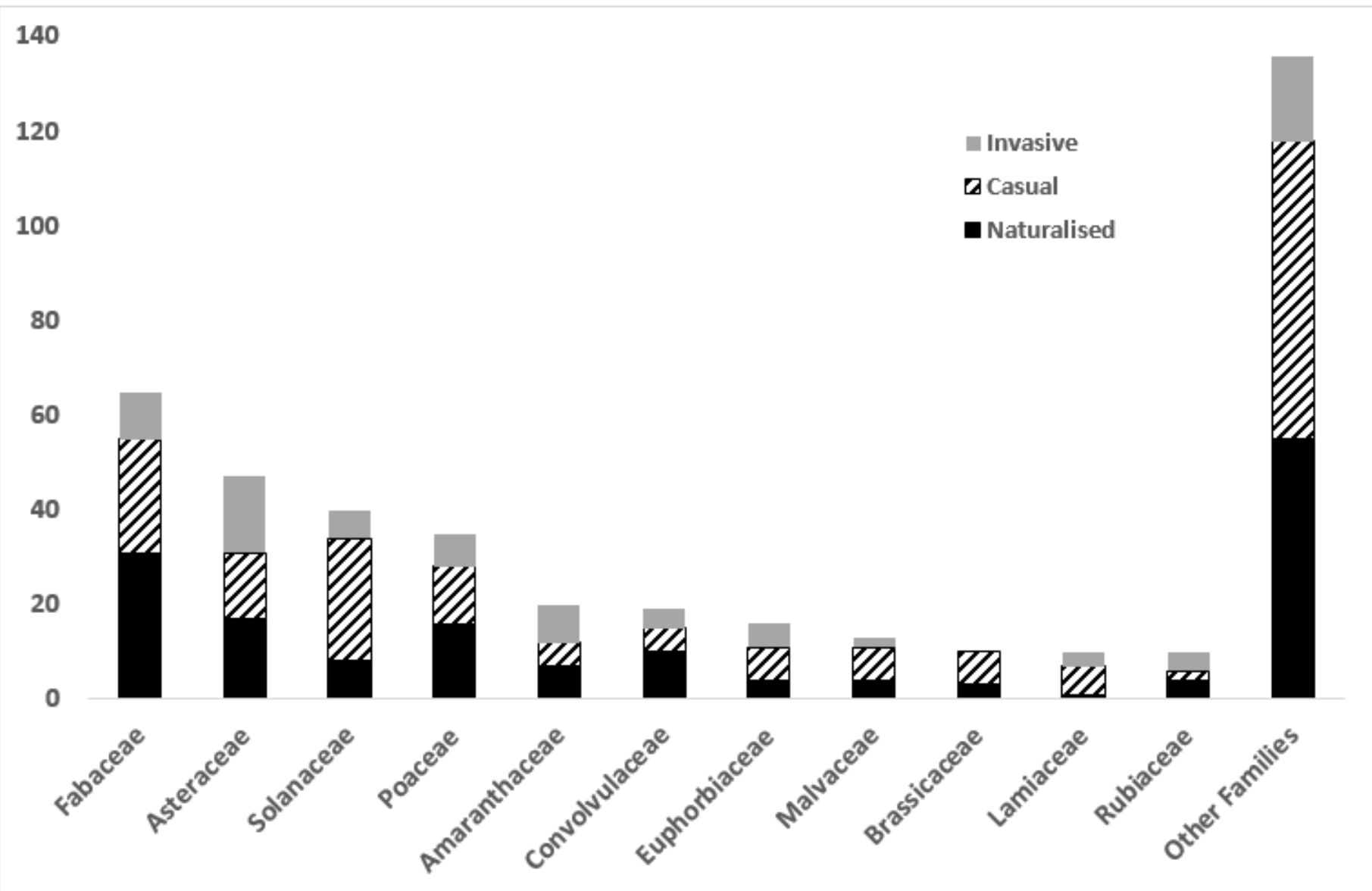

Figure 1

Taxonomic spectrum of the alien flora of D.R. Congo 


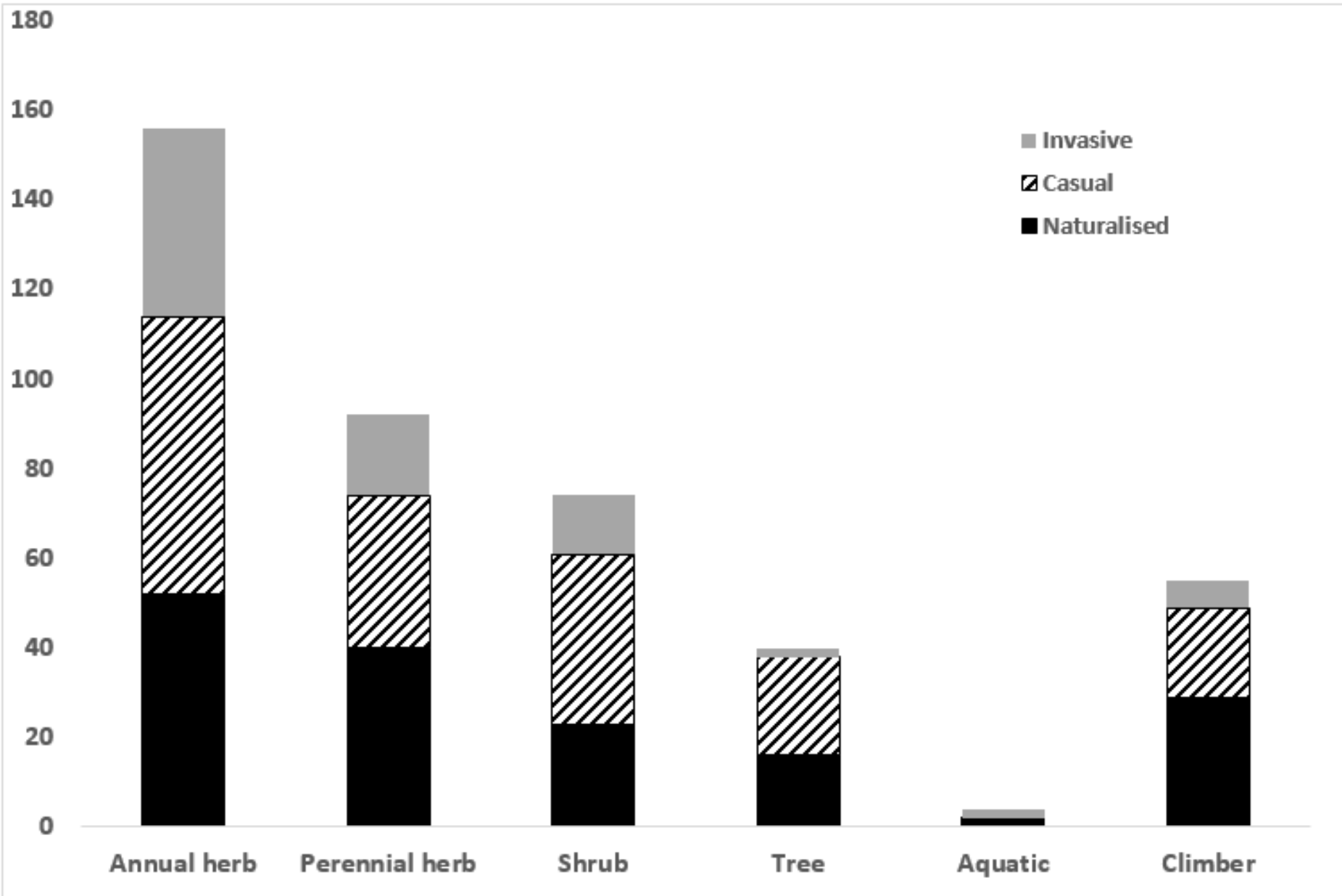

Figure 2

Life form spectrum of the alien flora of D.R. Congo 


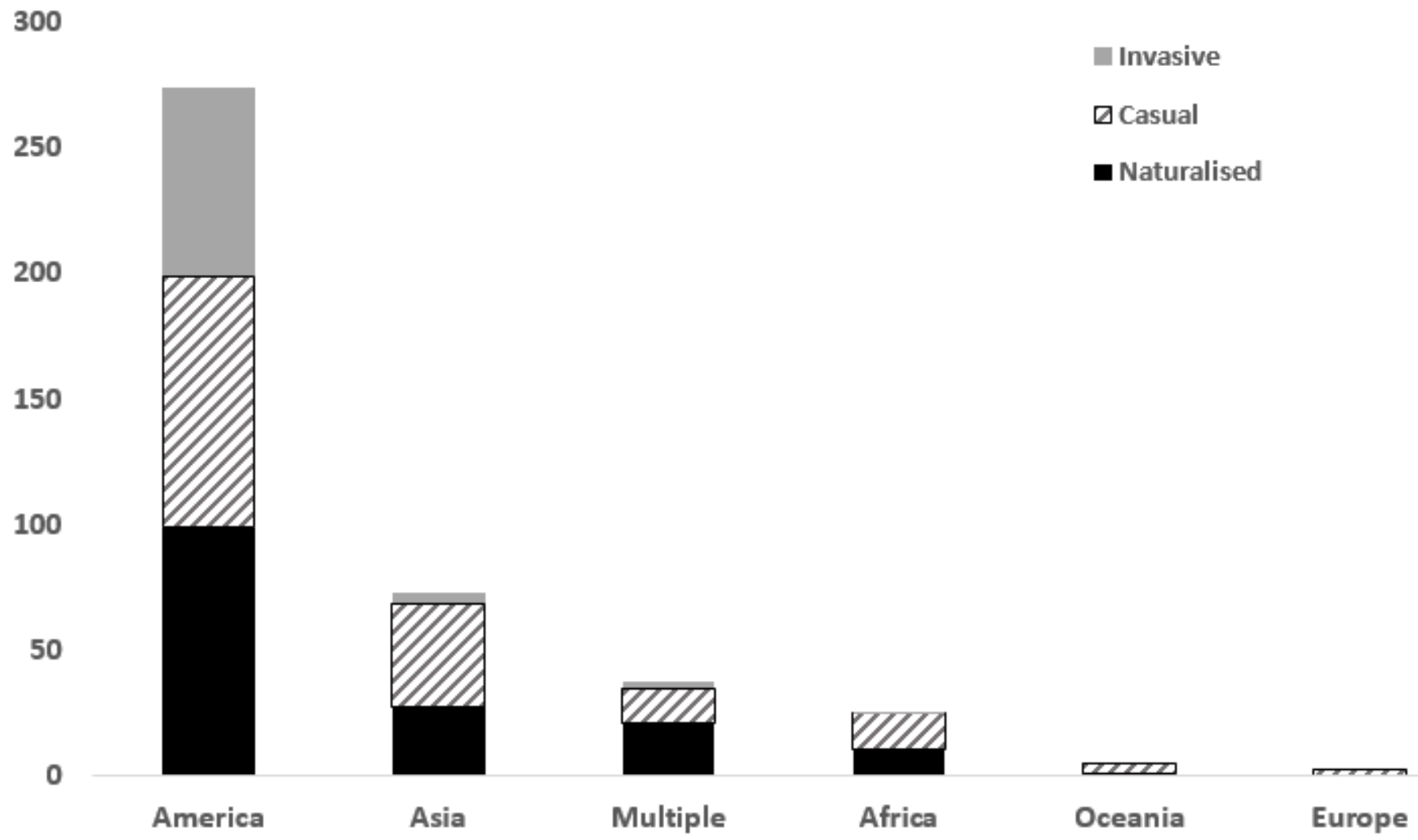

Figure 3

Phytogeographic spectrum of the alien flora of D.R. Congo 


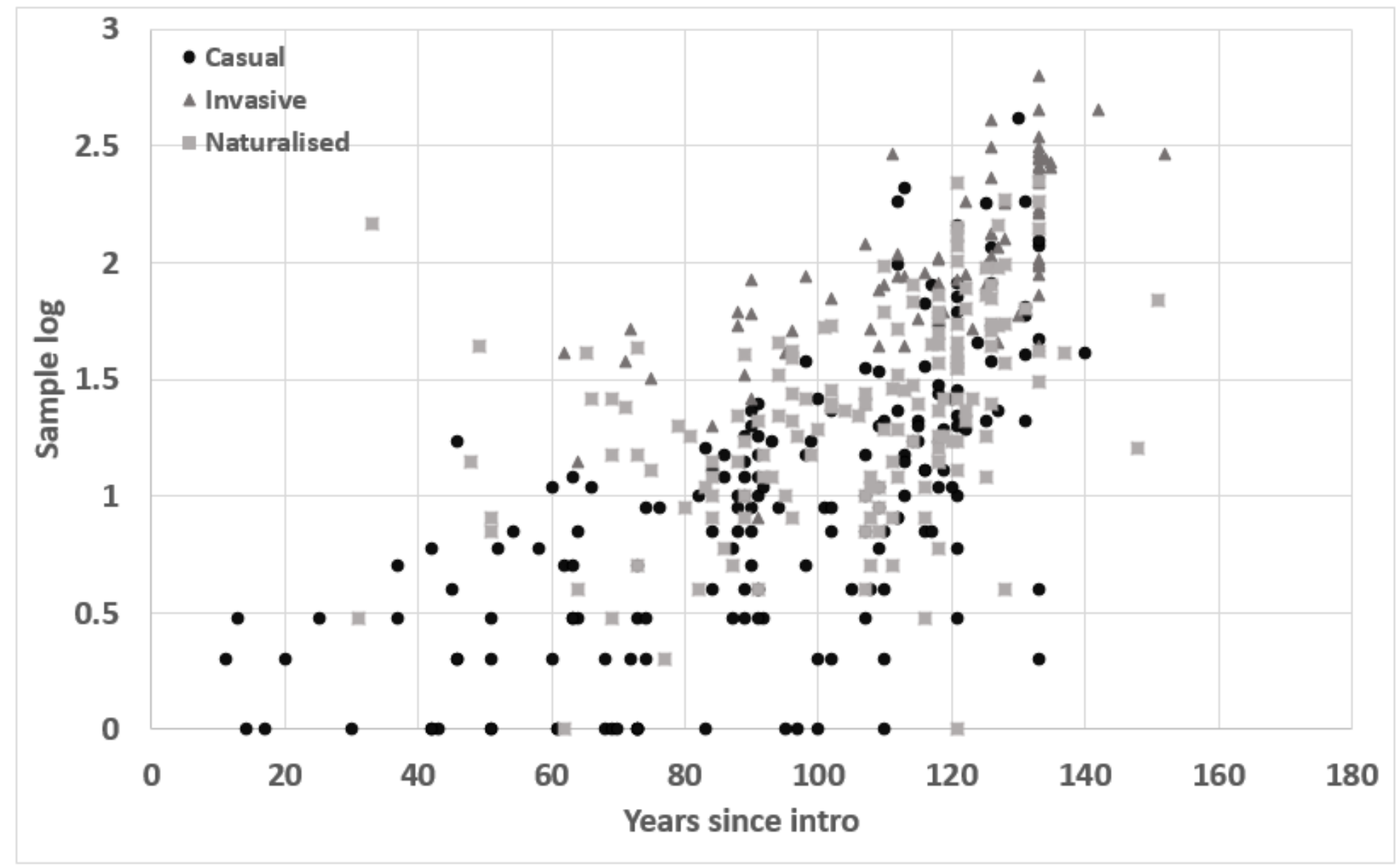

Figure 4

Number of specimens in collections as a function of time since first record. $Y=0.0135 X-0.30 r^{2}=0.43$ $\mathrm{P}<0.001$ 


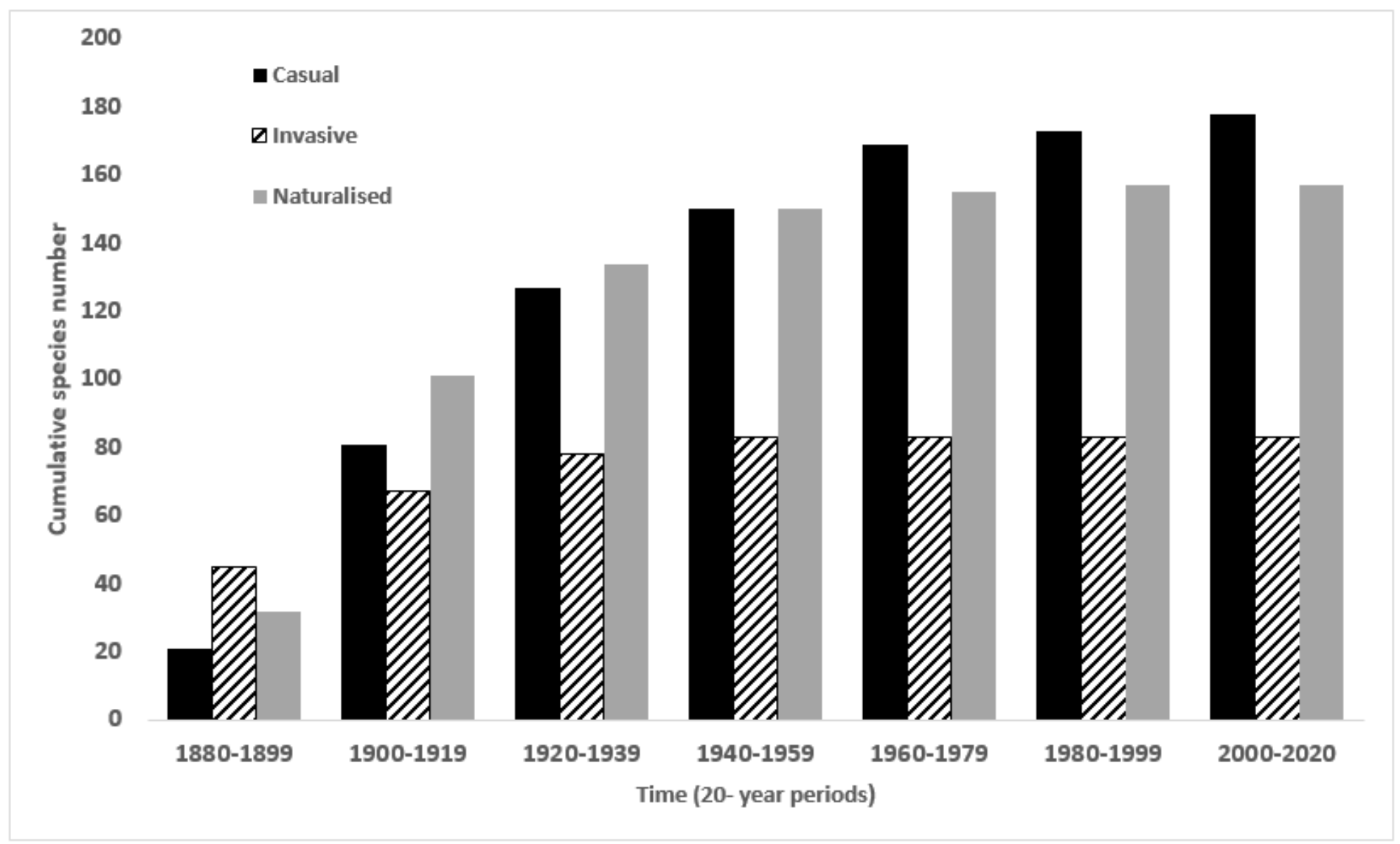

Figure 5

Number of species recorded as a function of time 


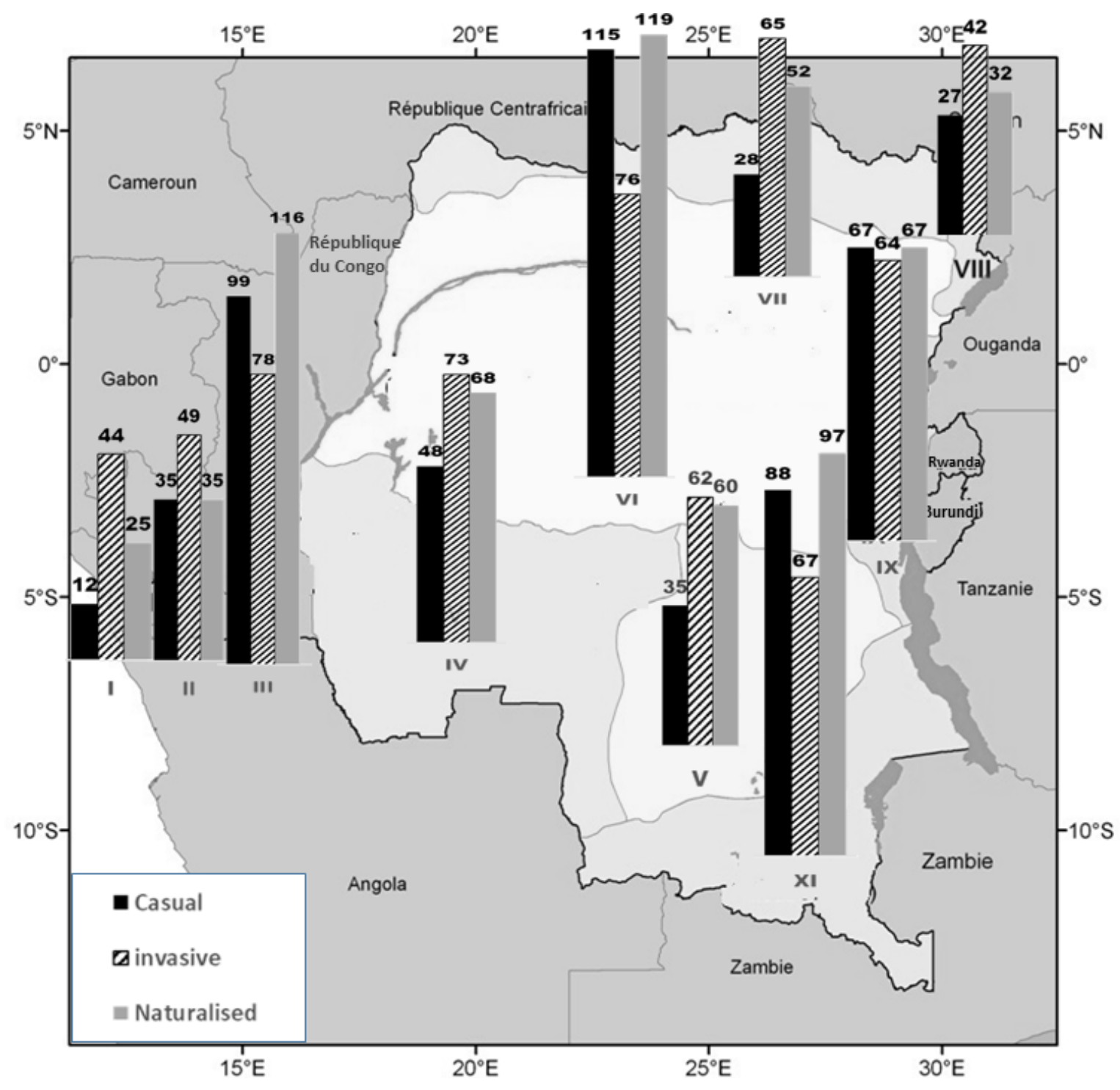

Figure 6

Alien species richness in the eleven phytogeographic regions of D.R. Congo. I. Côtier, II. Mayombe, III. BasCongo, IV. Kasaï, V. Bas-Katanga, VI. Forestier Central, VII. Ubangi-Uele, VIII. Lac Albert, IX. Lacs Edouard et Kivu. XI. Haut-Katanga Note: The designations employed and the presentation of the material on this map do not imply the expression of any opinion whatsoever on the part of Research Square concerning the legal status of any country, territory, city or area or of its authorities, or concerning the delimitation of its frontiers or boundaries. This map has been provided by the authors.

\section{Supplementary Files}

This is a list of supplementary files associated with this preprint. Click to download.

- SI1AlienfloraofDRCaccepted.xIsx

- S2discardedcultivated.xlsx

- S3discardednative.xlsx 
- S4othertaxaexcluded.xIsx

- S5newrecords.docx 